\title{
ABOUT RADIOCARBON IN ENVIRONMENTAL RESEARCHES IN UKRAIIIE
}

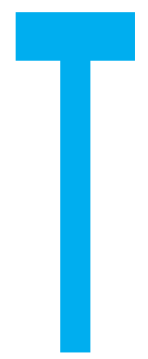

BUZYNNY M.G.

SI «O.M. Marzieiev Institute

for Public Health, NAMS Ukraine», Kyiv,

Ukraine he using of radiocarbon for environmental research in Ukraine was started by scientific team headed by E.V. Sobotovich [1]. In 1989, they drew attention to the excess of radiocarbon in the 1986 tree rings of pine tree, collected near the Chornobyl NPP, as related to nuclear accident. The main methodical aspects of sample preparation for radiocarbon research in environmental studies were assumed by Kovalukh and Skripkin [2]

The research results of the joint team of Institute of Environmental Geochemistry (IGNS) and the Scientific Center for Radiation Medicine (SCRM) showed significant spatial contrast of the determined radiocarbon accidental component [3] in the wood of 1986 annual tree rings, collected in different locations around Chornobyl NPP. It allows to illustrate the Chornobyl NPP's significant accidental gas emissions of ${ }^{14} \mathrm{C}$ along with operational releases, and also gave an estimate of the maximum concentration of ${ }^{14} \mathrm{C}$ among samples of graphite of the destroyed rector of the Chornobyl NPP by the value of $2.5 \cdot 10^{7} \mathrm{~Bq} / \mathrm{kg}$. The article also analyzes the possibility of

ПРО РАДІОВУГЛЕЦЬ В ЕКОЛОГІЧНИХ

ДОСЛІДЖЕННЯХ В УКРАЇНІ

Бузинний М.Г.

ДУ «Інститут громадського здоров'я ім. О.М. Марзєєва НАМН України», м. Київ, Україна

У статті представлено аналіз основних напрямків використання досліджень радіовуглецю в Україні для різноманітних завдань екології: викиди $\mathrm{CO}_{2}$ AEC i TEC, $\mathrm{CO}_{2}$ викиди транспорту, радіоактивний графіт і довкілля, баланс викидів $\mathrm{CO}_{2}$ в атмосферу. Дослідження стосувались штатних та аварійних умов роботи об'єктів енергетики, різних напрямків і застосування відповідних методичних розробок.

Дано коротку інформацію про основні результати, проблеми і перспективи. Приділено увагу деяким теоретичним та методичним питанням.

Ключові слова: екологія, радіовуглець, ${ }^{14 C}$, АEC, ТЕС, транспорт, викопне паливо. using the 1986 herbarium collection for retrospective studies of radiocarbon, emphasizing that these herbarium can have two components of ${ }^{14} \mathrm{C}$ pollution: structural, due to the absorption of $\mathrm{CO}_{2}$, and surface due to the deposition of radioactive graphite dust. At that time, according to research of the SCRM team, a hypothesis was proposed for the possible correlation of Chornobyl disaster radioactive components: ${ }^{14} \mathrm{C}$ and 131 , and the idea of using it to retrospectively determine the spatial distribution of 131 I in the air and in the thyroid gland of residents [4], which were relevant at the time. The ideas for the further development of ${ }^{14} \mathrm{C}$ studies in Chornobyl NPP's vicinity were published in 1994 [5].

To estimate the ${ }^{14} \mathrm{C}$ emissions of the Zaporizhzhya NPP in the form of $\mathrm{CO}_{2}$, corresponding annual tree rings were sampled along with one-off $\mathrm{CO}_{2}$ samples from a gas-aerosol discharge in ventilation pipe trapped in an alkaline. The agreed results were published in $1994[6,7]$-showing emissions rate up to $2.2 \mathrm{TBq}$ per year or totaled up to $12 \mathrm{TBq}$ during the observed period of 1985 to 1993. For those estimations were used empirical modeling approaches based on data published by M. McCartney et al. [8].

At the 15th International Radiocarbon Conference in 1994, corresponding scientific papers were submitted by an international team of authors, which included SCRM and IGNS staff on the distribution of ${ }^{14} \mathrm{C}$ in annual pine wood in the impact zone during the operation of the Tomsk spent fuel processing plant and about the evaluation of the relevant ${ }^{14} \mathrm{C}$ releases $[9,10]$. According to the estimates, the ${ }^{14} \mathrm{C}$ emissions in the form of $\mathrm{CO}_{2}$ was up to 30-45 TBq per year in 1985-1988 or up to $450-620 \mathrm{TBq}$ during the operation of the plant in 1959-1993.

( Бузинний М.Г. СТАТТЯ, 2020. 

ON RADIOCARBON IN THE ECOLOGICAL
RESEARCH IN UKRAINE

Buzynny M.G.

SI «O.M. MarzieievInstitute for Public Health, NAMSU», Kyiv, Ukraine

The article presents the analysis of main directions of the application of radiocarbon studies in Ukraine for various ecological tasks: $\mathrm{CO}_{2}$ emissions both nuclear power plants and thermal power plants, spatial distribution of $\mathrm{CO}_{2}$ due to transport emissions, radioactive graphite and environment, balance of carbon dioxide emissions into the atmosphere. The studies referred to the operation and emergency conditions of nuclear energy facilities, various directions, and the application of appropriate methodological developments. There is a short information on the main results, problems, and prospects.

A prominence has been given some theoretical and methodological issues.

Keywords: ecology, radiocarbon, ${ }^{14} \mathrm{C}$, NPP, TPP, transport, $\mathrm{CO}_{2}$ emissions, fossil fuel
Estimates were based on empirical model based on data published by M. McCartney et al. [8]. During the conference, in particular Teflon vials were presented, already developed by Ukrainian researchers as a part of instrumental development for ${ }^{14} \mathrm{C}$ measurement[10].

At the 16 th International Radiocarbon Conference in 1997, advanced research results on the environmental impact of the Chornobyl disaster were presented in the form of separate works by two teams of the SCRM and IGNS staff $[11,12]$. The first team examined more than 60 trees in the territory of the $30-\mathrm{km}$ exclusive zone of Chornobyl NPP, and evaluated the integrated spatial distribution of radiocarbon excess by (fig. 1). The simulation based on these data and local weather condition data allowed to estimate the total ${ }^{14} \mathrm{C}$ emission in $\mathrm{CO}_{2}$ from by $50 \mathrm{TBq}$, and the daily emissions value of several initial days of the active phase of the accident (fig. 2) [11]. In this paper, an estimate of the maximum dust-aerosol emission component of $60 \mathrm{TBq}$ was presented [11]. The other team considered some aspects of the environmental behavior of corresponding manmade ${ }^{14} \mathrm{C}$ componentsin the forest ecosystem [12]. Methodical developments for the so-called vacuum pyrolysis method along with set of equipment were presented at the conference. Technology approacheswere described in the article by Skripkin and Kovaliukh [13]. Nowadays much of modern radiocarbon laboratories are equipped with such equipment and make extensive use of the vacuum pyrolysis method mentioned above [1].

The results of subsequent Chornobyl-related ${ }^{14} \mathrm{C}$ studies conducted by the SCRM team were published in [15-17]. They related to the estimation of the $\mathrm{CO}_{2}$ operational emissions of ${ }^{14} \mathrm{C}$ of Chornobyl NPP by the content of ${ }^{14} \mathrm{C}$ in the several annual tree rings of two trees from the Chornobyl suburbs [15], where the estimated maximum value is $3.3 \mathrm{TBq}$ per year, or 20.8 TBq during of operation until 1996. Features of radioactive graphite dispersion in the environment (forest litter and soil, samples taken in 19961997) were investigated later during of 1998-2002 [16, 17].

The studies have already been refined by the same staff member in the SE «O.M. Marzieiev Institute of Public Health» in 2018 [18].

A certain summation of radioecological data related to ${ }^{14} \mathrm{C}$ carbon dioxide emissions of different nuclear power facilities at the former USSR under different conditions: operational and accidental was published in article in 2003 [19].

Environmental radiocarbon researches conducted in Ukraine during of 2013 concerned the effect of contrast changes in radiocarbon content in annual wood, which are related to the impact of global bomb effect or local impact of nuclear technology facilities on the secondary formation of

\section{Spatial Distribution of $\Delta{ }^{14} \mathrm{C}$ in Annual Wood Around Chornobyl NPP (Bq/ $\left.\mathbf{k g}^{-1} \mathrm{C}\right)$}

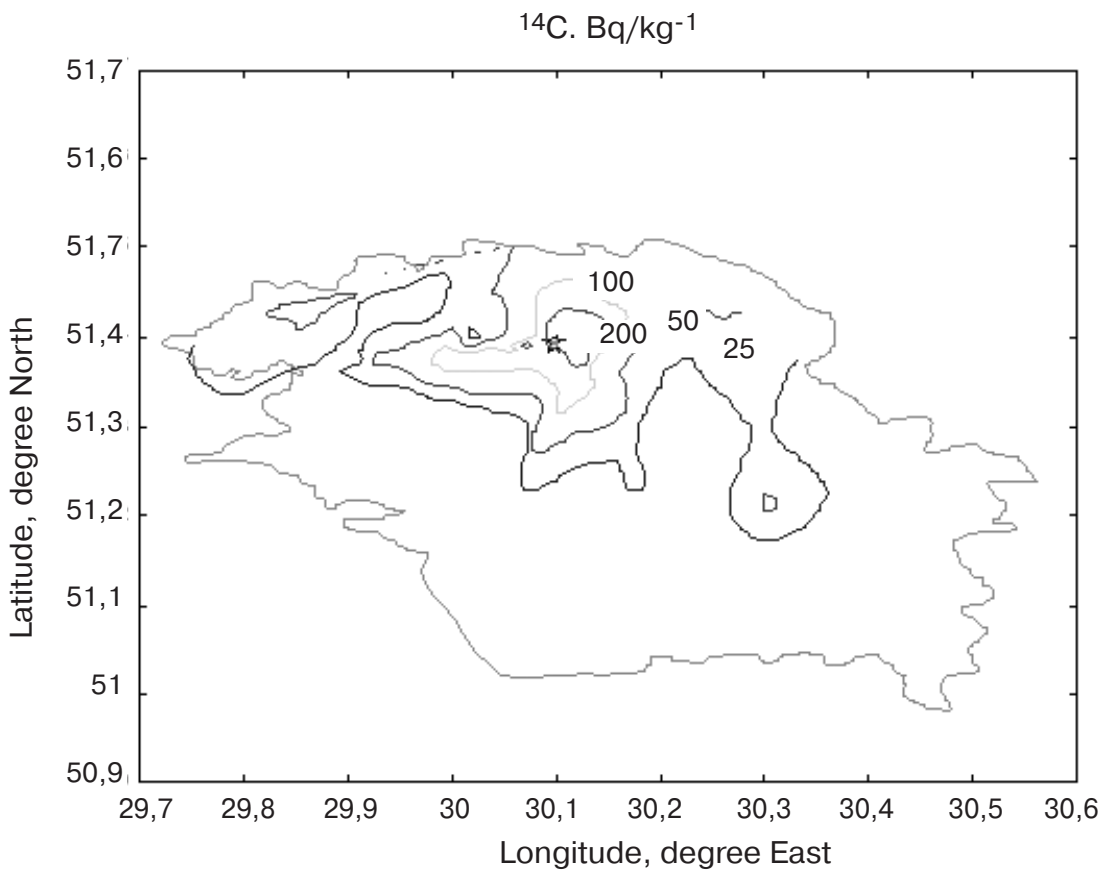


radiocarbon levels in annual tree rings, which already previously formed, due to the «moving fraction" [20]. The results of few yearly and several-year section timber studies show that the content of the ${ }^{14} \mathrm{C}$ «moving fraction» (volatile fraction)release during of the wooddestruction while sample preparation, differs from the coal component in anotherway, depending on the tendency for the ${ }^{14} \mathrm{C}$ level to change in the air. The contrast of their differences and the magnitude itself depend on the quality (depth) of the leaching of extractives from wood using of solid to liquid phase extraction (Soxhlet apparatus).

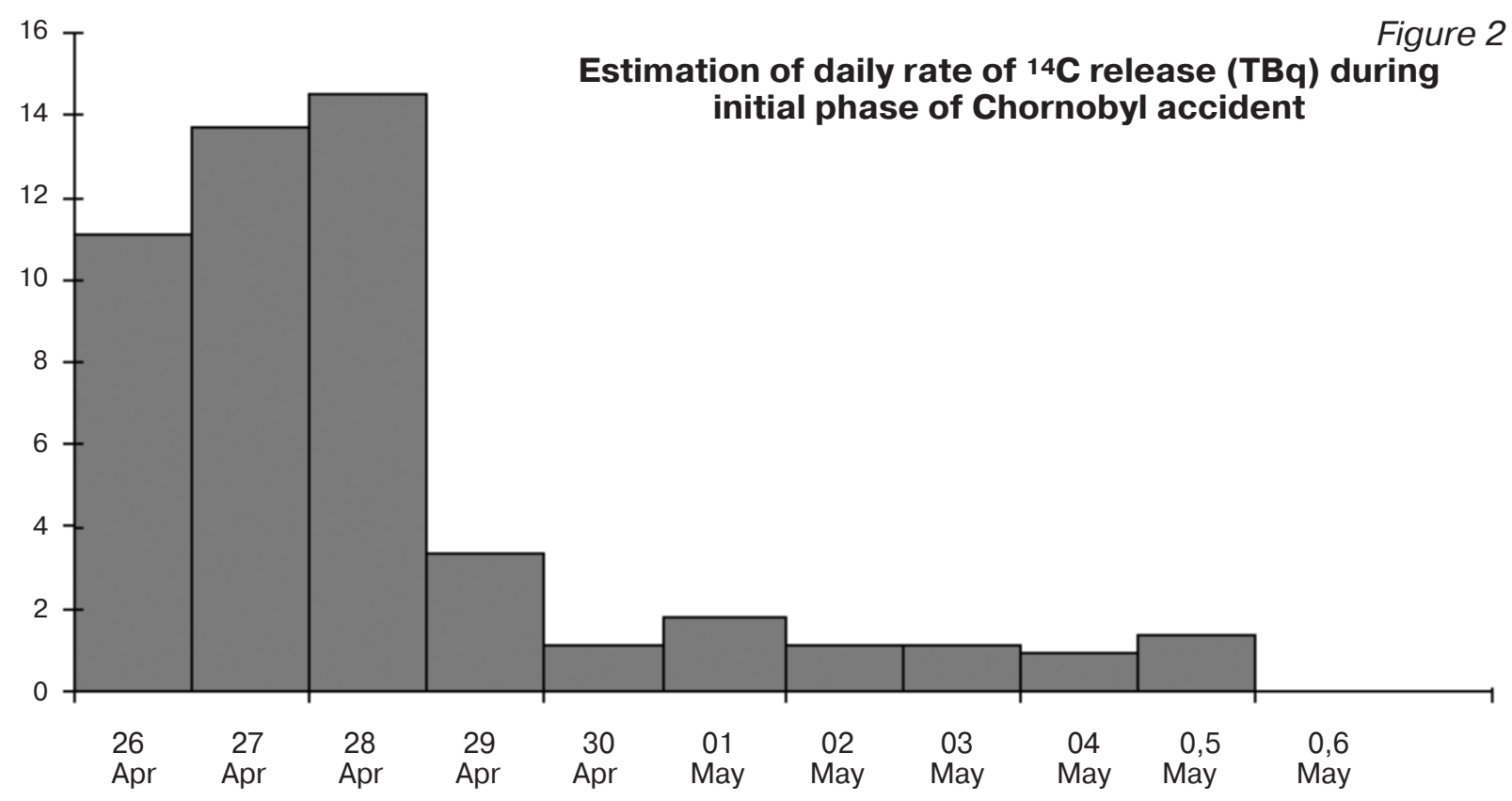

Excessive ${ }^{14} \mathrm{C}(\mathrm{Bq} / \mathrm{kg})$ in annual wood of pinetree, collected around intensive industrial source (distances: 5 km upper and 10 km lower)

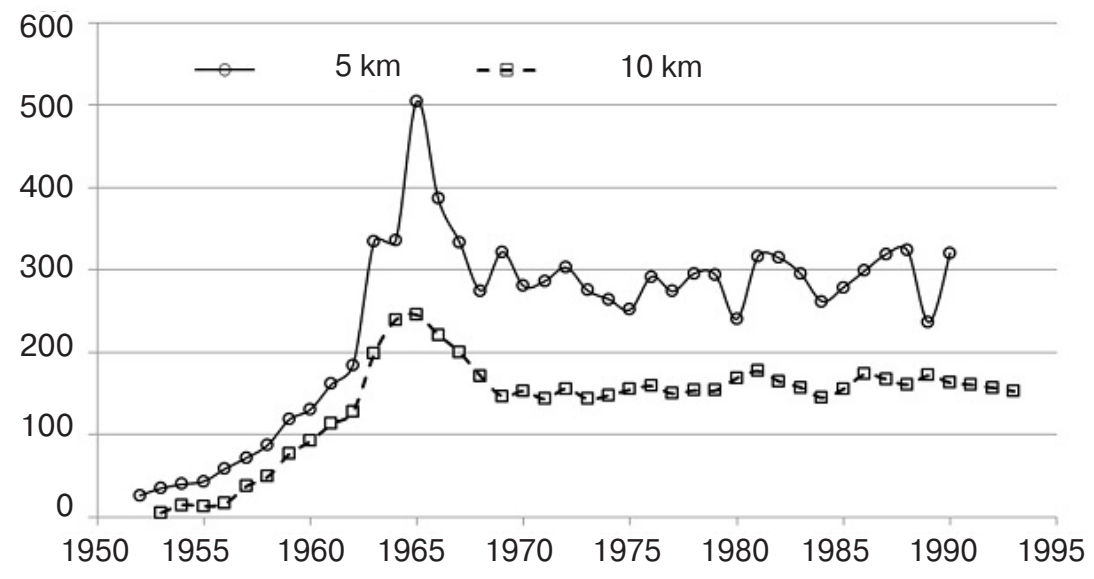

Investigated wood of the «background» tree showed acceptable quality of pre-treatment of wood for the interval of annual rings corresponding to the «bomb effect», i.e. after 1955. Obviously, for pre-1955 annual timber, a deeper pre-treatment is required. Another paper published in 2014 [22] outlined an updated range of current applications of radiocarbon research for environmental purposes, such as the already known annual wood, annual and crop production studies, for assessments of local pollution of urban areas, estimates of renewable fuel components.

Investigation of peculiarities of formation of local anomalies of
Figure 2
Figure 3

(po

different scale of $\mathrm{CO}_{2}$ distribution in the area of influence of power plants and transport based on fossil fuel combustion are devoted to articles published in 2015 (fig. 4) [23, 24].

Radioactivewaste management problem includes issues of their stabilization and transformation for long storage and disposal. It is shown, that spent Chernobyl radioactive graphite is one of the objects which require its proper conversion [25].

To estimate the $\mathrm{CO}_{2}$ emissions balance into the atmosphere, a component that arisesdue to combustion of solid recovered fuel generated from household wastes, it is neces- 


\section{О РАДИОУГЛЕРОДЕ В ЭКОЛОГИЧЕСКИХ ИССЛЕДОВАНИЯХ В УКРАИНЕ \\ Бузынный М.Г. \\ ГУ «Институт общественного здоровья им. А.Н. Марзеева НАМН Украины», г. Киев, Украина}

В статье представлен анализ основных направлений использования исследований радиоуглерода в Украине для различных задач экологии: выбросы $\mathrm{CO}_{2}$ АЭС и ТЭС, выбросы $\mathrm{CO}_{2}$ транспорта, радиоактивный графит и окружающая среда, баланс выбросов $\mathrm{CO}_{2}$ в атмосферу. Исследования касались штатных и аварийных условий работы объектов энергетики, различных направлений и применений соответствующих методических разработок. Дана краткая информация об основных результатах, проблемах и перспективах. Обращается внимание на некоторые теоретические и методические вопросы.

\section{Ключевые слова: экология,} радиоуглерод, ${ }^{14 C}$, АЭС, ТЭС, транспорт, ископаемое топливо. sary to determine the fraction of modern Carbon material in the average ${ }^{14} \mathrm{C}$ samples. Methodic approach of such analyses based on vacuum pyrolysis [13] are well tested and described in [26].

\section{ЛІТЕРАТУРА}

1. Соботович Э.В., Ковалюх Н.Н., Чебаненко С.И. Дендрорадиоэкология в зоне влияния Чернобыльской АЭС. Принципы и методы ландшафтно-геохимических исследований миграции радионуклидов: сб. тез. Всесоюзн. совещ. М., 1989. C. 125.

2. Ковалюх Н.Н., Скрипкин В.В. Химическая подготовка образцов для радиоэкологических исследований радиоуглерода. Радиоизотопы в экологических исследованиях. К. : Наукова думка, 1992. С. 93-101.

3. Бузынный М.Г., Зеленский А.В., Ковалюх Н.Н., Скрипкин В.В., Санин Е.В. Ретроспективное восстановление уровня аварийного выброса ${ }^{14} \mathrm{C}$ в атмосферу вследствие аварии на Чернобыльской АЭС. Актуальные вопросы ретроспективной, текущей и прогнозной дозиметрии облучения в результате Чернобыльской аварии: матер. науч. конф. К., 1993. С. 118-124.

4. Бузынный М.Г., Лось И.П., Зеленский А.В.,

Ковалюх Н.Н., Скрипкин В.В. О возможной корреляции уровней ${ }^{14} \mathrm{C}$ в растительности с ${ }^{131}$ в в щитовидной железе после аварии на ЧАЭС. Актуальные проблемы ликвидации медицинских последствий аварии на Чернобыль- ской АЭС : тез. докл. укр. науч. -практ. конф. Часть I. Киев, 1993. С. 48-49.

5. Kovalyukh N., Skripkin V., Sobotovich E., Buzinny M., Sanin E. Radiocarbon of accidental release of Chornobyl NPP in annual tree rings. Geochronometria. 1994. Vol. 10. P. 217-224.

6. Зеленский А.В., Бузынный М.Г. Энергетическая калибровка жидкостно-сцинтилляционного бета-спектрометра. Актуальные проблемы ликвидации медицинских последствий аварии на Чернобыльской АЭС : тезисы докл. научно-практ. конф. Киев, 1993. Ч. І. С. 126.

7. Buzinny M., Kovaliukh N., Los I., Skripkin V. Radiocarbon releases of Zaporozhye NPP. Geochronology and Dendrochronology of Old
Town's and Radiocarbon Dating of Archaeological Findings: Proc. Conf. Vilnius : Vilnius University Press, 1994. P. 7-12.

8. McCartney M., Baxter M.S., Scott E.M. Carbon-14 discharges from the nuclear fuel cycle: Local effects. Journal of Environmental Radioactivity. 1988. Vol. 8. Is. 2. P. 157-171. https://doi.org/10.1016/0265931X(88)90023-9.

9. Buzinny M., Kovalyukh N., Likhtarjov I., Los I., Nesvetajlo V., Pazdur M. Sobotovich E. Ecological Chronology of Nuclear Fuel Cycle Sites. Radiocarbon. 1995. Vol. 37 (2). P. 469-473. doi: 10.1017/S0033822200030940. 10. Buzinny M., Skripkin V. Newly Designed 0.8-ML Teflon ${ }^{\circledR}$ Vial for Microvolume Radiocarbon Dating.

\section{Spatial distribution of ${ }^{14} \mathrm{C}$ in grass samples (pMC), collected near high traffic highway \\ (Pechersk district of Kyiv Druzhby Narodiv Boulevard, profile I with repetition and profile II)}

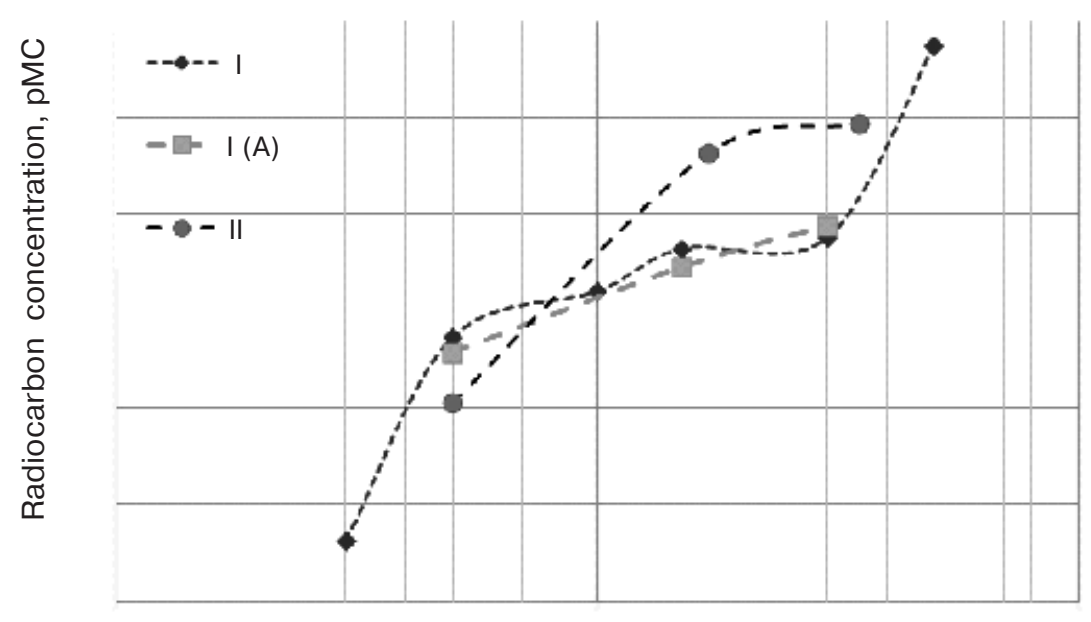

Distance, $\mathrm{m}$

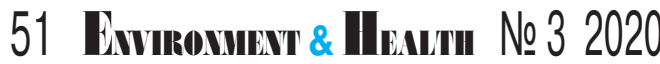


Radiocarbon. 1995. Vol. 37

(2). P. 743-747. doi:10.1017/ S0033822200031283.

11. Buzinny M., Likhtarev I., Los I., Talerko N., Tsigankov N. ${ }^{14} \mathrm{C}$ Analysis of Annual Tree Rings from the Vicinity of the Chornobyl NPP. Radiocarbon. 1997. Vol. 40 (1). P. 373-379. doi: $10.1017 /$ S0033822200018 25.

12. Kovaliukh N., Skripkin V., Van Der Plicht J. ${ }^{14} \mathrm{C}$ Cycle in the Hot Zone Around Chornobyl. Radiocarbon. 1997. Vol. 40 (1). P. 391-397. doi:10.1017/S0033822200018 270.

13. Skripkin V., Kovaliukh N. Recent Developments in the Procedures Used at the Sscer Laboratory for the Routine Preparation of Lithium Carbide. Radiocarbon. 1997. Vol. 40 (1). P. 211-214. doi:10.1017/ S0033822200018063.

14. Benzene Line. Chemical Equipment for ${ }^{14} \mathrm{C}$ Dating. URL: http://benzene-line.com

15. Бузинний М.Г., Талерко М.М. Штатні викиди Чорнобильської АЕС. Гігієна населених місць : зб. наук. пр. К., 2000. Вип. 36 (1). C. 234-242.

16. Бузинний М.Г., Талерко М.М. Ретроспективні дослідження радіовуглецю Чорнобильського аварійного викиду. Гігієна населених місць : зб. наук. пр. К., 2000. Вип. 36 (1). С. 246-260.

17. Buzinny M. Radioactive Graphite Dispersion in the Environment in the Vicinity of the Chornobyl Nuclear Power Plant. Radiocarbon. 2006. Vol. 48 (3). P. 451-458. doi:10. 1017/S003382220003887X.

18. Бузинний М., Скрипкін В. Дослідження радіоактивного графіту у лісовій підстилці. Довкілля та здоров'я. 2018. № 3 (88). C. 71-74. doi:10.32402/dovkil2018.03.071

19. Бузынный М.Г. Уровни выбросов радиоуглерода объектов ядерного топливно-энергетического комплекса на территории бывшего СССР. Збірник наукових праць Інституту ядерних досліджень. К., 2003. Вип. 1 (9).

C. $110-119$.
20. Бузинний М.Г. Особливості розподілу радіовуглецю у фракціях деревини останнього сторіччя. Гігієна населених місць: зб. наук. пр. К., 2013. Вип. 61. С. 254-258.

URL: http://nbuv.gov.ua/

UJRN/gnm_201361_42

21. Бузинний М.Г., Михайлова Л.Л., Романченко М.О., Чирков В.С., Сахно В.І. До питання ретроспективного дослідження ${ }^{14} \mathrm{C}$ в атмосфері. Довкілля та здоров'я. 2014. № 3. C. 43-46. URL:

http://nbuv.gov.ua/UJRN/dtz 2014_3 10

22. Бузинний М.Г., Гуленко С.В., Михайлова Л.Л., Романченко М.O., Сахно B.I. Радіовуглець як маркер сучасних антропогенних змін у довкіллі. Гігієна населених місць: зб. наук. пр. К., 2014. Вип. 63. С. 200-207.

23. Бузинний М.Г., Гуленко С.В., Романченко М.О., Чирков В.С., Михайлова Л.Л., Сахно В.І. Розподіл радіовуглецю у траві поблизу автомагістралей. Гігієна населених місць: зб. наук. пр. К., 2015. Вип. 66. С. 168-175. URL: http://nbuv.gov.ua/UJRN/gnm 20156627

24. Skripkin V.V., Buzynny M.G. Teflon Vials For Precise ${ }^{14} \mathrm{C}$ in Benzene Measurements by LSC. Technique Biological and Chemical Research. 2017. Vol. 4 (9). P. 229-233. URL: http://www.ss-pub.org/wpcontent/uploads/2017/09/BC R2017052201.pdf.

25. Zlobenko B., Fedorenko Y., Yatcenko V., Shabalin B., Skripkin V. Investigation on Conversion of I-graphite from Decommissioning of Chornobyl NPP into a Stable Waste Form Acceptable for Long Term Storage and Disposal. IAEA-TECDOC-1790: Report. Vienna: IAEA, 2016. $15 \mathrm{p}$

26. Бузинний М.Г. Підхід до оцінки відсоткової частки органічної фракції у паливі з відходів на основі технологій синтезу бензолу та РСЛ радіовуглецю. Актуальні питання гігієни та екологічної безпеки України (XIII марзєєвські читання) : зб. тез наук. - пр. конф. К., 2017. Вип. 17. С. 149-150.

\section{REFERENCES}

1. Sobotovich E.V., Kovalyukh N.N. and Chebanenko S.I. Dendroradioekologiya v zone vliyaniya Chernobylskoy AES [Dendroradioecology in a Zone of the Influence of the Chernobyl NPP]. In : Printsipy $i$ metody landshaftno-

geokhimicheskikh issledovaniy migratsii radionuklidov: sb. tez. vsesoyuzn. Soveshch

[Principles and Methods of Landscape and Geochemical Studies of Radionuclide Migration: Coll. Thesis. AllUnion Conf.]. Moscow ; 1989 : 125 (in Russian).

2. Kovalyukh N.N. and Skripkin V.V. Khimicheskaya podgotovka obraztsov dlya radioekologicheskikh issledovaniy radiougleroda [Chemical Preparation of Samples for Radioecological Studies of Radiocarbon]. In : Radioizotopy $v$ ekologicheskikh issledovaniyakh : sb. nauch. tr. [Radioisotopes in the Environmental Studies: Coll. Sci. Works]. Kiev : Naukova dumka; 1992 : 93-101 (in Russian).

3. Buzynnyy M.G., Zelenskiy A.V., Kovalyukh N.N., Skripkin V.V. and Sanin E.V. Retrospektivnoye vosstanovleniye urovnya avariynogo vybrosa ${ }^{14} \mathrm{C}$ v atmosferu vsledstviye avarii na Chernobylskoy AES

[Retrospective Restoration of the Level of Emergency Emission of ${ }^{14} \mathrm{C}$ into the Atmosphere Due to the Accident at the Chernobyl NPP]. In : Aktualnyye voprosy retrospektivnoy. tekushchey $i$ prognoznoy dozimetrii oblucheniya $v$ rezultate Chernobylskoy avarii: mater. nauch. konf. [lssues of Retrospective, Current and Forecast Radiation Dosimetry as a Result of the Accident at the Chernobyl NPP : Proc. Sci. Conf.]. Kiev ; 1993 : 118-124 (in Russian).

4. Buzynnyy M.G., Los I.P., Zelenskiy A.V., Kovalyukh N.N. and Skripkin V.V. O vozmozhnoy korrelyatsii urovney ${ }^{14} \mathrm{C} v$ rastitelnosti s 131 | v shchitovidnoy zheleze posle avarii na ChAES [On a Possible 
Correlation of ${ }^{14} \mathrm{C}$ Levels in Vegetation with ${ }^{131}$ I in the Thyroid Gland after the Accident at the ChNPP]. In : Aktualnyye problemy likvidatsii meditsinskikh posledstviy avarii na Chernobylskoy AES: tez. nauch.-prakt. konf.

[CurrentProblems of the Elimination of the Medical Consequences of the Accidentat the Chernobyl NPP: Thesis of the Sci.-Pract. Conf.]. Kiev ; 1993; 1 : 48-49 (in Russian).

5. Kovalyukh N., Skripkin V., Sobotovich E., Buzinny M.and Sanin E. Radiocarbon of Accidental Release of Chornobyl NPP in Annual Tree Rings. Geochronometria. 1994;10 :217-224.

6. Zelenskiy A.V. and Buzynnyy M.G.

Energeticheskaya kalibrovka zhidkostno-stsintillyatsionnogo beta-spektrometra [Energy Calibration of a Liquid Scintillation Beta Spectrometer]. In: Aktualnyye problemy likvidatsii meditsinskikh posledstviy avarii na Chernobylskoy AES : tezisy nauchno-prakt. konf. [Current Problems of the Elimination of the Medical Consequences of the Accident at the Chernobyl NPP: Thesis of the Sci.-Pract. Conf.]. Kiev ; 1993 ; I : 126 (in Russian).

7. Buzinny M., Kovaliukh N., Los I. and Skripkin V.

Radiocarbon Releases of Zaporozhye NPP. Geochronology and Dendrochronology of Old Town's and Radiocarbon Dating of Archaeological Findings: Proc. Conf. Vilnius (Lituva):

Vilnius University Press ; 1994 : 7-12.

8. McCartney M., Baxter M.S. and Scott E.M. Carbon-14 Discharges from the Nuclear Fuel Cycle: Local Effects. Journal of Environmental Radioactivity. 1988 ; 8 (2) : 157-171. https://doi.org/10.1016/0265931X(88)90023-9.

9. Buzinny M., Kovalyukh N., Likhtarjov I., Los I., Nesvetajlo V., Pazdur M. and Sobotovich E. Ecological
Chronology of Nuclear Fuel Cycle Sites. Radiocarbon. 1995 ; 37(2) : 469-473. doi: $10.1017 /$ S0033822200030 940.

10. Buzinny M. and Skripkin V. Newly Designed 0.8-ML Teflon $®$ Vial for Microvolume Radiocarbon Dating. Radiocarbon. 1995 ; 37(2) : 743-747 doi: $10.1017 / S 0033822200031$ 283.

11. Buzinny M., Likhtarev I., Los I., Talerko N. and

Tsigankov N. ${ }^{14} \mathrm{C}$ Analysis of Annual Tree Rings from the Vicinity of the Chornobyl NPP. Radiocarbon.

1997 ; 40 (1) : 373-379. doi: $10.1017 /$ S0033822200018 25.

12. Kovaliukh N., Skripkin V. and Van Der Plicht J. ${ }^{14} \mathrm{C}$ Cycle in the Hot Zone Around Chornobyl. Radiocarbon. 1997 ; 40 (1) : 391-397. doi: $10.1017 /$ S0033822200018270

13. Skripkin V. and Kovaliukh N. Recent Developments in the Procedures Used at the Sscer Laboratory for the Routine Preparation of Lithium Carbide. Radiocarbon.

1997 ; 40 (1) : 211-214.

doi: $10.1017 / S 0033822200018$ 063.

14. Benzene Line. Chemical Equipment for ${ }^{14} \mathrm{C}$ Dating. URL: http://benzene-line.com

15. Buzynnyi M.H. and

Talerko M.M. Shtatni vykydy

Chornobylskoi AES [Chornobyl

NPP Emissions]. In : Hihiiena

naselenykh mists : zb. nayk. pr. [Hygiene of Settlements :

Sci. Works Coll.]. Kyiv ;

2000 ; 36 (1) : 234-242

(in Ukrainian).

16. Buzynny M.H. and

Talerko M.M. Retrospektyvni doslidzhennia radiovuhletsiu Chornobylskoho avariinoho vykydu [Retrospective Studies of Radiocarbon Emissions of the Chornobyl Accident]. In : Hihiiena naselenykh mists: zb. nayk. pr. [Hygiene of

Settlements : Sci. Works Coll.]. Kyiv ; 2000 ; 36 (1) : 246-260 (in Ukrainian).

17. Buzinny M. Radioactive Graphite Dispersion in the Environment in the Vicinity of the Chornobyl Nuclear Power Plant. Radiocarbon.
2006 ; 48(3) : 451-458. doi: $10.1017 / S 0033822200038$ 87X.

18. Buzynny M. and Skrypkin V. Doslidzhennia radioaktyvnoho hrafitu u lisovii pidstyltsi [Investigation of Radioactive Graphite in Forest Floor]. Dovkillia ta zdorovia (Environment \& Health). 2018 ; 3 (88) : 71-74. doi:10.32402/dovkil2018.03.071

(in Ukrainian)

19. Buzynny M.G. Urovni vybrosov radiougleroda obyektov yadernogo toplivno-energeticheskogo kompleksa na territorii byvshego SSSR [Radiocarbon Emission Levels of Nuclear Fuel and Energy Facilities in the Former USSR]. In : Zbirnyk naukovykh prats Instytutu yadernykh doslidzhen [Proceedings of the Institute of Nuclear Research]. Kyiv ; 2003 ; 1(9) : 110-119

(in Russian).

20. Buzynny M.G.

Osoblyvosti rozpodilu radiovuhletsiu u fraktsiiakh derevyny ostannoho storichchia [Features of Radiocarbon Distribution in Wood Fractions of the Last Century]. In : Hihiiena naselenykh mists : zb. nauk. pr. [Hygiene of Settlements : Sci. Works Coll.]. Kyiv ; 2013 ; 61 : 254-258. URL:

http://nbuv.gov.ua/UJRN/gnm 2013_61_42

(in Ukrainian).

21. Buzynny M.G., Mykhailova L.L., Romanchenko M.O. Chyrkov V.S. and Sakhno V.I.

До питання ретроспективного дослідження ${ }^{14} \mathrm{C}$ в атмосферi. Do pytannia retrospektyvnoho doslidzhennia ${ }^{14} \mathrm{C}$ v atmosferi [To the Issue of a Retrospective Study of ${ }^{14} \mathrm{C}$ in the Atmosphere]. Dovkillia ta zdorovia (Environment \& Health). 2014 ; 3 : 43-46. URL: http://nbuv.gov.ua/UJRN/dtz 2014310

(in Ukrainian).

22. Buzynnyi M.G., Hulenko S.V., Mykhailova L.L., Romanchenko M.O. and Sakhno V.I. Radiovuhlets yak marker suchasnykh antropohennykh zmin v dovkilli [Radiocarbon as a Marker of Modern Anthropogenic 
Changes in the Environment]. In: Hihiiena naselenykh mists : zb. nauk. pr. [Hygiene of Settlements : Sci. Works Coll.]. Kyiv ; 2014 ; 63 : 200-207 (in Ukrainian).

23. Buzynny M.G., Hulenko S.V., Romanchenko M.O., Chyrkov V.S., Mykhailova L.L. and Sakhno V.I. Rozpodil radiovuhletsiu v travi poblyzu avtomahistralei [Radiocarbon Distributin in Grass near Highways]. In: Hihiiena naselenykh mists : zb. nauk. pr. [Hygiene of Settlements : Sci. Works Coll.]. Kyiv ; 2015 ; 66 : 168-175. URL:

http://nbuv.gov.ua/UJRN/gnm 2015_66_27

(in Ukrainian).

24. Skripkin V.V. and Buzynnyi M.G. Teflon Vials For Precise C-14 in Benzene Measurements by LSC. Technique Biological and Chemical Research. 2017 ; 4 (9) : 229-233. URL: http://www.ss-pub.org/wpcontent/uploads/2017/09/BC R2017052201.pdf.

25. Zlobenko B., Fedorenko Y., Yatcenko V., Shabalin B. and Skripkin V. Investigation on Conversion of I-graphite fromDecommissioning of Chernobyl NPP into a Stable Waste FormAcceptable for Long Term Storage and Disposal. IAEA-TECDOC-1790: Report. Vienna : IAEA ; 2016 : 15 p.

26. Buzynny M.G. Pidkhid do otsinky vidsotkovoi chastky orhanichnoi fraktsii u palyvi z vidkhodiv na osnovi tekhnolohii syntezu benzolu ta RSL radiovuhletsiu [Approach to the Estimation of Percentage of Organic Fraction in Fuel from Waste on the Basis of Technology of Synthesis of Benzene and RSL of Radiocarbon]. In : Aktualni pytannia hihiieny ta ekolohichnoi bezpeky Ukrainy (XIII marzieievski chytannia) : zb. tez nauk. -pr. konf. [Current Issues of Hygiene and Ecological Safety of Ukraine (The Thirteenth Marzieiev's Reading) : Sci.Pract. Conf. Thesis Coll.]. Kyiv ; $2017 ; 17: 149-150$ (in Ukrainian).

Надійшло до редакції 15.03.2020 https://doi.org/10.32402/ dovkil2020.03.054

THE IMPACT OF DIRECT AND INDIRECT INDICATOR PARAMETERS OF ARCHITECTURAL-AND-PLANNING DECISIONS OF THE INSTITUTIONS OF SECONDARY EDUCATION ON PSYCHOEMOTIONAL STAIE AND HEALTH OF PRIMARY SCHOOL AGE PUPILS

Pavlenko N.P., Makhniuk V.M., Voloshchuk O.V.

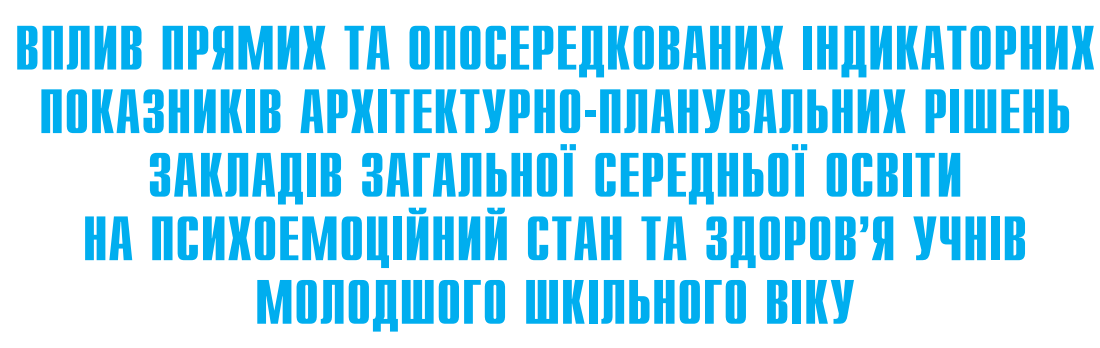

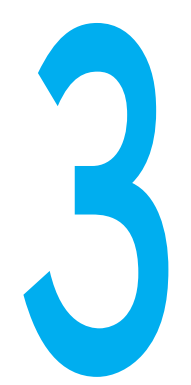

ПАВЛЕНКО Н.П., МАХНЮК В.М., ВОЛОЩУК О.В

ДУ «Інститут громадського здоров'я ім. О.М. Марзєєва НАМН України", м. Київ, Україна а сучасним містобудівним законодавством, заклади загальної середньої освіти (З3СО) є об'єктами громадського обслуговування населення сельбищної території, за санітарним - об'єктами з високим ризиком санітарно-епідеміологічного неблагополуччя та об'єктами підвищеного епідемічного ризику [1-3].

Період життя, протягом якого учень перебуває у приміщенні школи, $€$ важливим етапом біологічного та психофізіологічного розвитку дитячого організму. Ранній початок систематичного навчання, нові навчальні програми, педагогічні технології без гігієнічного супроводу за відсутності медичного забезпечення $€$ випробовуванням для дитячого організму, його фізичної та соціальної зрілості, особливо для дітей молодшого шкіль-

ВПЛИВ ПРЯМИХ ТА ОПОСЕРЕДКОВАНИХ ІНДИКАТОРНИХ ПОКАЗНИКІВ АРХІТЕКТУРНО-ПЛАНУВАЛЬНИХ РІШЕНЬ ЗАКЛАДІВ ЗАГАЛЬНОЇ СЕРЕДНЬОЇ ОСВІТИ

НА ПСИХОЕМОЦІЙНИЙ СТАН ТА ЗДОРОВ'Я УЧНІВ

МОЛОДШОГО ШКІЛЬНОГО ВІКУ

Павленко Н.П., Махнюк В.М., Волощук О.В.

ДУ «Інститут громадського здоров'я ім. О.М. Марзєєва НАМН України», м. Київ, Україна

Мета роботи. Удосконалення гігієнічних критеріїв забезпечення оптимальних умов перебування, навчання та збереження здоров'я школярів молодших класів, які є спільними для оцінки архітектурно-планувальних рішень міських та сільських ЗЗСО відповідно до сучасного містобудівного та санітарного законодавства. Матеріали та методи. Бібліосемантичний, аналітичний, санітарно-епідеміологічної експертизи проектів будівництва, соціологічний, інструментальний та медико-статистичний з використанням пакетів прикладних програм StatSoft STATISTICA (v.5.5), Excel.

Результати. Перевищення в 1,8-2,3 рази кількості фактичних досліджень, що не відповідають нормативам щодо природного

С Павленко Н.П., Махнюк В.М., Волощук О.В. СТАТТЯ, 2020. 